\title{
Szelektív MCL-1 inhibitorok felfedezése
}

\author{
KOTSCHY András* \\ Servier Kutatóintézet Zrt., Záhony u 7., 1031 Budapest, Magyarország
}

\section{Bevezetés}

A programozott sejthalál, és ennek egyik fontos formája, az apoptózis a veszélyt jelentő sejtek eltávolításának egyik fontos útvonala. ${ }^{1} \mathrm{Az}$ apoptózis elkerülése a rák kifejlődésének és a különböző terápiás kezelésekkel szembeni rezisztencia kialakulásának alapjelensége. ${ }^{2}$ Az általunk vizsgált MCL-1 fehérje a BCL-2 fehérjecsalád tagja, mely fehérjecsalád felelős a mitokondriális apoptózis kontrolljáért. A ráksejtekben mennyiségük, különösen az MCL-1-é, gyakran emelkedett. ${ }^{3}$ Több leírt, a génexpressziót vagy fehérjeszintézist általánosan gátló gyógyszerjelölt tumorsejtekre kifejtett citotoxikus hatásáért is (legalább részben) az MCL1 fehérje szintjének csökkentése felel. ${ }^{4}$

Ezen elözmények után nem meglepö, hogy a BCL-2 fehérjecsalád és azon belül az MCL-1 is évtizedek óta a gyógyszerkutatók célpontjában van. A kitartó munka eredményeként a szelektív BCL-2 inhibitor venetoclax (Venclexta ${ }^{\circledR}$ ) mára engedélyezett gyógyszer a CLL (krónikus limfocitás leukémia) és AML (akut mieloid leukémia) betegek gyógyításában. ${ }^{5}$ Az első hatékony és szelektív MCL-1 gátlók megjelenéséig 2016-ig kellett várni. E vegyületek közül több jelenleg klinikai vizsgálati fázisban van. ${ }^{6}$ Jelen közleményben az elmúlt évtizedben az MCL-1 gátlók felfedezése terén végzett kutatásainkról adunk áttekintést.

\section{Saját eredmények}

A gyógyszerkutatási program elején létre kellett hoznunk a szükséges eszköztárat, melynek segítségével a kémiai kiindulópontként szolgáló fragmenseket azonosítani tudtuk. ${ }^{7}$ A folyamat következő stádiumában a fragmenseket az MCL1-et szelektíven gátló, sejtes aktivitást mutató vezérmolekulává fejlesztettük. ${ }^{8}$ Ezt a vezérmolekula optimálásával nyert, in vivo aktivitást mutató S63845 molekula azonosítása követte, mely már alkalmas volt a célpont biológiai validálására is. ${ }^{9} \mathrm{~A}$ folyamat záró fázisában a további optimálás eredményeként eljutottunk az S64315 klinikai kandidátushoz, melynek humán vizsgálata jelenleg is zajlik. ${ }^{10}$

Egy gyógyszerkutatási program elindításakor nélkülözhetetlen a megfelelő reagensek előállítása és a vizsgálati módszerek kifejlesztése és validálása. A sejtekben a programozott sejthalál féken tartásáért az úgynevezett antiapoptotikus BCL-2 fehérjecsalád (BCL-2, BCL- $\mathrm{x}_{\mathrm{L}}, \mathrm{MCL}-1$, BCL-w, BFL-1) és a sejthalált előidéző ún. BH3 fehérjék (pl. BIM, BAD, BAX, NOXA, PUMA) egyensúlya felel. E két család elemei egymással stabil komplexeket alkotnak, így a citoszolban alacsony a szabad BH3 fehérjék szintje. $\mathrm{Az}$ 1. ábra az MCL-1 és BIM fehérjék komplexének röntgenszerkezetét mutatja. Gyógyszerkutatási programunk alapfeltevése az volt, hogy amennyiben egy, az MCL-1-hez erősen kötődő kismolekula segítségével ki tudjuk szorítani a BIM-et és rokonfehérjéit az MCL-1-gyel alkotott komplexeikből a ráksejtben, akkor a citoszolban feldúsuló BH3 fehérjék visszafordíthatatlanul elindítják a programozott sejthalált, ami a ráksejt pusztulásához vezet. Míg az egészséges sejtek általában a BCL-2 fehérjecsalád több tagjára is támaszkodnak a belső egyensúly fenntartásában, addig a ráksejtekben jellemzően egy-egy antiapoptotikus fehérje feldúsulása biztosítja a ráksejt túlélését, így az MCL-1 függő daganatok esetében bízhattunk ezen sejtek szelektív elpusztításában.

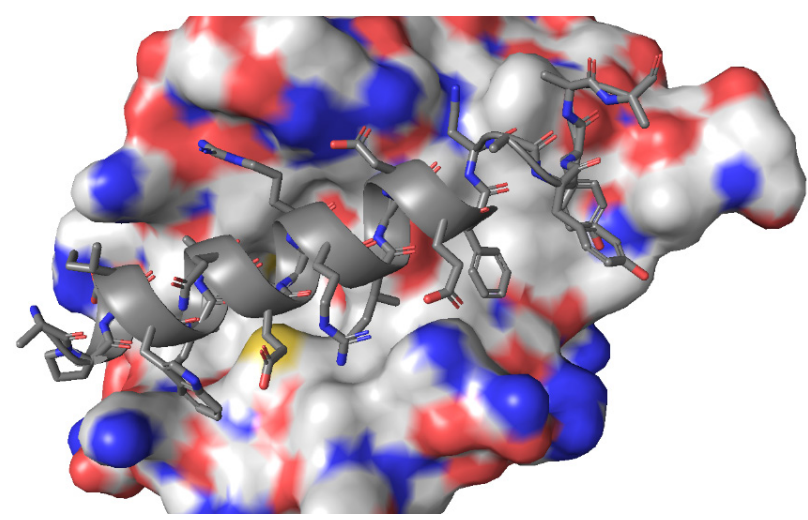

1. Ábra. Humán MCL-1 fehérje BIM komplexének röntgenszerkezete (PDB:6QFI)

A helikális elrendeződést mutató BH3 fehérjék nM affinitással kötődnek a BCL-2 család tagjaihoz. A fehérje-fehérje kölcsönhatási felület, az ún. „BH3-groove” viszonylag hidrofób, kevés erős kölcsönhatásra ad lehetőséget a kismolekula és a célfehérje között. Emiatt sokáig elképzelhetetlennek tartották, hogy gyógyszer fejleszthető e megközelítéssel (ún. undruggable célpont). A kutatási folyamat elején előállítottuk a 350 aminosavból álló humán MCL-1 fehérje BH3 kötőrégióját (171-327 aminosavak), mely alkalmas volt biofizikai vizsgálatok, pl. izotermális titrálásos kalorimetria (ITC) elvégzésére, és melynek a BIM-mel alkotott komplexét sikeresen kristályosítottuk (1. ábra). A BIM fehérje fluoreszcensen jelölt analogonjait felhasználva olyan fluoreszcencia polarizáció (FP) mérésen alapuló módszert dolgoztunk ki, amellyel nagy áteresztőképességel határozhattuk meg a vegyületeink MCL-1-hez való kötődését az $1 \mathrm{nM}-100 \mu \mathrm{M}$ tartományban.?

\footnotetext{
* Tel.: +36-1-881-2000; e-mail: andras.kotschy@servier.com
} 


\subsection{Kiindulópontok azonosítása}

A kémiai kiindulópontok azonosítására NMR alapú fragmensszürést használtunk, melynek során 8 fragmensből álló keverékekhez adtuk az MCL-1 fehérjét és vizsgáltuk a fragmensekre jellemző ${ }^{1} \mathrm{H}$ NMR jelek intenzitásának változását különböző mérési módszerek (STD, water-LOGSY, CPMG) között. Annak bizonyítására, hogy egy adott fragmens a BH3 fehérje helyére köt, a méréseket elvégeztük hozzáadott NOXA fehérje jelenlétében is. Több mint 1100 fragmensböl kiindulva 40 olyan vegyületet azonosítottunk, melyek több technikával vizsgálva is kötődést mutattak és a NOXA hatására megszűnt a kötődésük. Mivel a BCL-2 fehérjecsaládon belül fontos volt az MCL-1 szelektív gátlása, így a fragmensek esetében az MCL-1 mellett a BCL-2höz való kötődésüket is vizsgáltuk FP módszerrel. A 2. ábra néhány fragmens találat szerkezetét, valamint az MCL-1 és BCL-2 kötődési értékeit mutatja be. Ezen vegyületek (15) közös jellemzője, hogy a $\mu \mathrm{M}$ tartományban kötődnek a célfehérjéhez és nem mutatnak szelektivitást a BCL-2 fehérjével szemben. Mind az öt fragmens találat karbonsav részletet tartalmaz, amely az MCL-1 fehérje egyik Arg oldalláncával képez ionos kapcsolatot. Ennek hiányában a fragmensek kötődése több nagyságrenddel gyengül. E gyengén kötődő fragmensek esetében célszerű a fehérjekötődési vizsgálatokat két különböző elven müködő (ún. ortogonális) módszerrel is elvégezni. A mi esetünkben NMR HSQC titrálásokat, valamint izotermális titrálási kalorimetriát (ITC) használtunk erre a célra, melyek az elsődleges FP mérésekhez hasonló eredményt adtak.
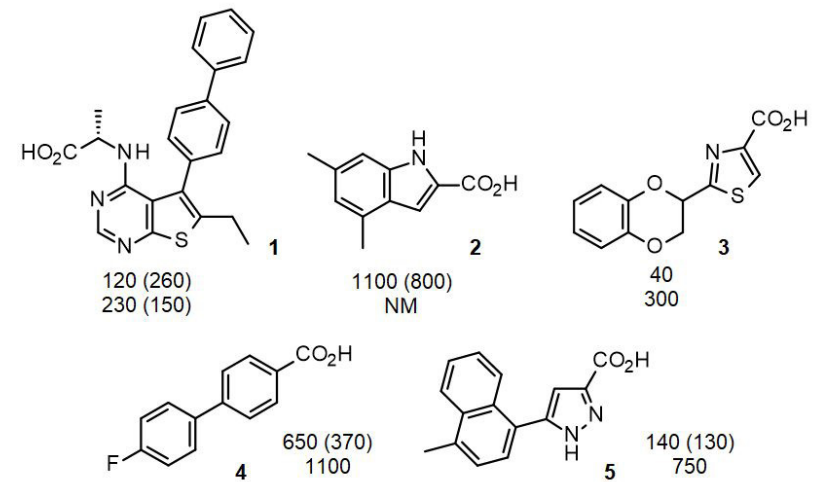

2. Ábra. Az NMR fragmensszüréssel azonosított néhány találat szerkezete, MCL-1 (felső szám) és BCL-2 (alsó szám) kötődése FP mérésekből számított $\mathrm{eK}_{\mathrm{i}}$ értékek $\mu \mathrm{M}$-ban kifejezve, zárójelben HSQC NMR $\mathrm{K}_{\mathrm{d}}$ értékek. NM - nem mérhető 2,5 mM koncentrációig.

Az azonosított fragmensek MCL-1 komplexeiröl nem sikerült szerkezeti információt szereznünk, így a validálás során szisztematikusan változtattuk a szerkezetüket és vizsgáltuk ennek hatását az MCL-1-hez való kötődésükre. Az elsődleges eredmények alapján figyelmünk elsősorban a tieno[2,3-d]pirimidinvázas 1 fragmens származékaira összpontosult. Ennek az alapváznak előnye, hogy a gyürürendszer szénatomjaira a különböző helyettesítők beépítése általában jó hatékonysággal megoldható. Így előállítottuk többek között a kisméretű helyettesítőket hordozó 6 vegyületet, melynek affinitása hasonló volt a kiindulópontunkhoz
(3. Ábra). A gyürüváz 5-ös helyzetébe difeniléter-csoportot építve (7) mind az MCL-1, mind a BCL-2 affinitás $20 \mu \mathrm{M}$ alá csökkent, amit az NMR $\mathrm{K}_{\mathrm{d}}$ mérések is megerösítettek. További, hasonló mértékű javulást értünk el, amikor a pirimidingyűrü 2-es helyzetébe aromás helyettesítőt építettünk be (8). Ezek a változtatások látszólag jó irányba vezetnek, de ha figyelembe vesszük, hogy milyen mértékű móltömeg növekedést „,szenvedett el” a molekulánk, akkor rögtön látszik, hogy nem hatékonyak. Jól példázza ezt a 9-es molekula is, mely jóval kisebb mérete ellenére számottevő kötődést mutat mindkét vizsgált fehérjéhez, így őt választottuk a további fragmensoptimálás kiindulópontjának. A részletesebb szerkezet-hatás összefüggést vizsgálva arra a következtetésre jutottunk, hogy ezen kisméretű vegyületek esetében többféle kötődési mód is előfordulhat, ami nehezíti az eredmények értelmezését.
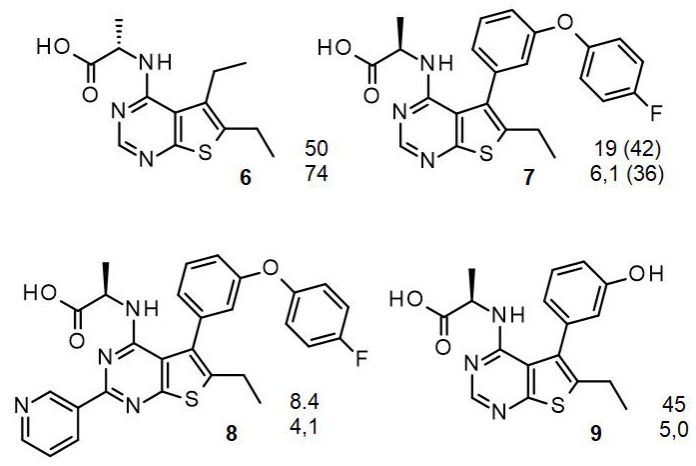

3. Ábra. A tienopirimidin-vázas fragmens találat kémiai validálása. MCL-1 (felső szám) és BCL-2 (alsó szám) kötődés FP mérésekből számított $\mathrm{eK}_{\mathrm{i}}$ értékei $\mu \mathrm{M}$-ban kifejezve, zárójelben HSQC NMR $\mathrm{K}_{\mathrm{d}}$ értékek.

\subsection{Fragmens optimálása vezérmolekulává}

A 9-es fragmens optimálásának egyik fontos része volt az 5-ös helyzetü benzolgyürü szubsztitúciós mintázatának változtatása (4. Ábra). E folyamat során váratlan módon, a fenilcsoportot orto-tolilra cserélve (10), jelentős változást értünk el a vegyület szelektivitásában. Míg az MCL-1-hez való kötődés a $\mu \mathrm{M}$ tartományban maradt, a BCL-2 kötődés elromlott.

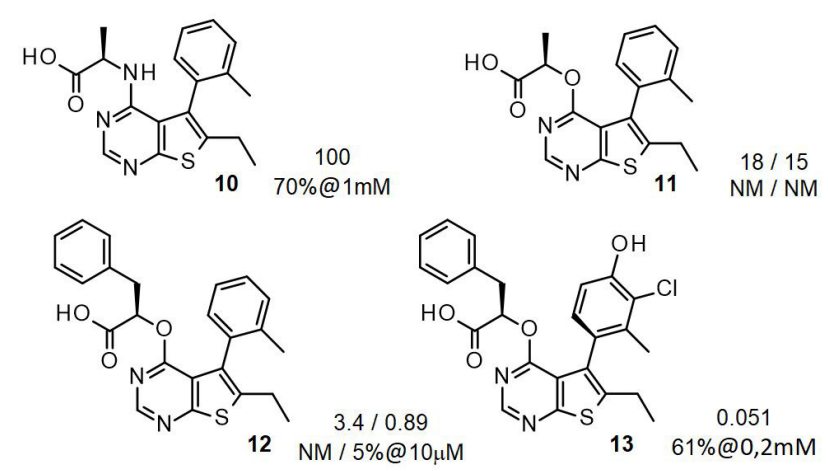

4. Ábra. A tienopirimidin-vázas fragmens optimálásának korai fázisa. MCL-1 (felső szám) és BCL-2 (alsó szám) kötődés FP mérésekből számított eKi értékei $\mu \mathrm{M}$-ban kifejezve. Részleges görbe esetén a legnagyobb koncentrációnál mért hatást tüntettük fel. NM - nem mérhető 2,5 mM koncentrációig. 
Még markánsabb lett ez a hatás, amikor az aminosavat hidroxisavra cseréltük. Az orto-tolil helyettesítő gátolt rotációja miatt a $\mathbf{1 1}$ vegyület diasztereomerek keverékeként keletkezett, melyeket kromatográfiásan el tudtunk választani. Mindkét atropoizomer hasonló, $20 \mu \mathrm{M}$ alatti affinitást mutatott az MCL-1-hez, míg BCL-2 kötődésük nem volt mérhető.

A tejsav részlet növelésével (12) szintén számottevő javulást sikerült elérnünk: az MCL-1 kötődést a nM tartományba vittük, míg a szelektivitás továbbra is jelentős maradt. Hasonló, majd további hússzoros javulást értünk el a benzolgyürü szubsztitúciós mintázatának finomhangolásával. A 13, diasztereoizomertiszta vegyület $51 \mathrm{nM}$ kötődést mutatott az MCL-1 fehérjéhez. Ebben szerepet játszott az aromás gyürühöz kapcsolódó klóratom és a fehérje peptidvázának egy közeli karbonilcsoportja között kialakuló másodlagos kölcsönhatás, ún. halogénkötés is, mely a röntgenszerkezetekben jól látható.

Bár az előállított vegyületeink hatékonyan és szelektíven kötődtek az MCL-1 fehérjéhez, a sejtes vizsgálatok során nem mutatták a várt apoptózis indukáló hatást. Feltételezésünk szerint ennek elsődleges oka a gyenge sejtpenetrációs készség lehetett, amely elsősorban a karboxilcsoport fiziológiás körülmények között mutatott állandó negatív töltéséből eredhetett. Ennek ellensúlyozására különbözö bázikus csoportokat építettünk be molekulánk aromás gyürüjére (5. Ábra). A szerkezeti biológiai vizsgálatok egyértelműen mutatták, hogy ezek a csoportok az oldószerfázis felé néznek, így nem rontják el a fehérjéhez való kötődést. A 14 vegyület például $32 \mathrm{nM}$ kötődést mutatott és mellette a H929 sejtvonalon vizsgálva megfigyeltük a programozott sejthalál beindítását $15,5 \mu \mathrm{M} \mathrm{IC} \mathrm{I}_{50}$ értékkel.
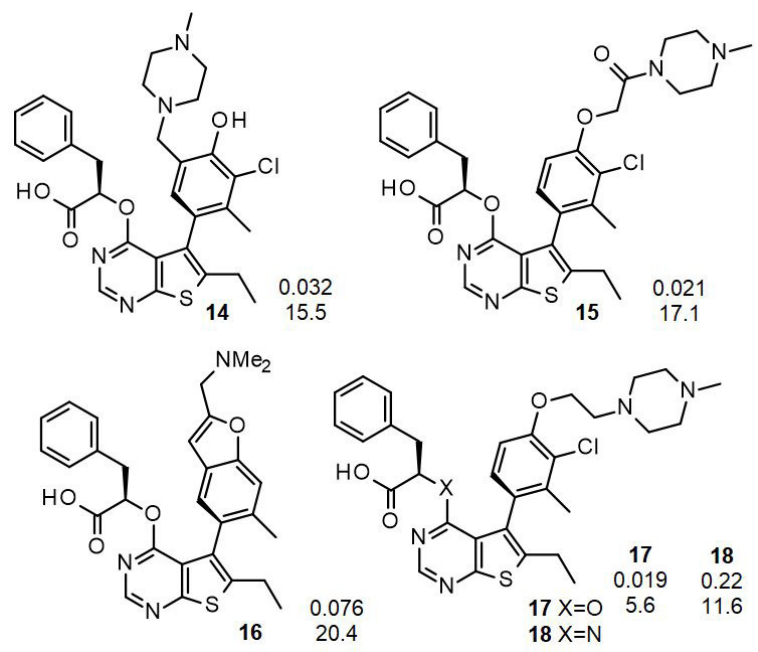

5. Ábra. Az MCL-1 gátló vezérmolekula kiválasztása. MCL-1 kötődés FP mérésekből számított eKi értéke $\mu \mathrm{M}$-ban kifejezve (felső szám) és H929 sejtpusztítás $\mathrm{IC}_{50}$ értéke $\mu \mathrm{M}$-ban kifejezve MTT módszerrel (alsó szám).

A 15 és 16 vegyületek hasonló affinitást és sejtes aktivitást mutattak, megerősítve, hogy a bázisos nitrogén jelenléte fontos, míg pontos elhelyezkedése kevésbé. Ugyanakkor fontos megemlíteni, hogy a nitrogénatom megfelelő bázi- citása kulcsfontosságú volt a sejtes aktivitás szempontjából. $\mathrm{Az}$ aminocsoport változtatása általában a sejtes aktivitás gyors letöréséhez vezetett.

A legjobb affinitást és sejtes aktivitást abban az esetben értük el, amikor a bázikus csoportot etilénláncon keresztül kötöttük a fenol részlethez. A számos vizsgált amin közül az $N$-metil-piperazin részlet esetében (17) kiváló $19 \mathrm{nM}$ kötődést és 5,6 $\mu \mathrm{M}$ sejtes aktivitást mértünk. A vegyület diasztereoizomerei kivétel nélkül jóval gyengébb kötődést mutattak. Elkészítettük e molekula aminosav analogonját is (18), amely valamivel gyengébb kötődést és aktivitást mutatott a hidroxisavnál. A 17 vegyületet részletes jellemzése (in vitro ADME és biztonságossági vizsgálatok, in vivo $\mathrm{PK}$ ) után vezérmolekulának tekintettük és belőle kiindulva folytattuk az optimálási folyamatot.

\subsection{A vezérmolekula optimálása és a célpont biológiai validálása}

A kutatás ezen stádiumában sikerült meghatároznunk 17 MCL-1-gyel alkotott komplexének röntgenkrisztallográ-fiás szerkezetét (6. Ábra). A tienopirimidin részlet a fehérje ún. S2-es kötőzsebébe mélyen benyúlik és azt szinte teljesen kitölti. E régióban az egyetlen növekedési lehetőségnek (6. Ábra kiegészítő kép) a gyürüváz 6-os helyzetü etilcsoportjának kismértékü változtatása tünt. Az 5-ös helyzetü tetraszubsztituált benzolgyürü esetében nem láttuk értelmét a további átalakításoknak. A 4-es helyzetü tejsavszármazék esetében az építkezés kézenfekvő helye a fenilcsoport volt, ezen belül is a benzolgyürü orto-helyzete, mely lehetöséget kínált a fehérje távolabbi, ún. S4 kötőzsebének elérésére.

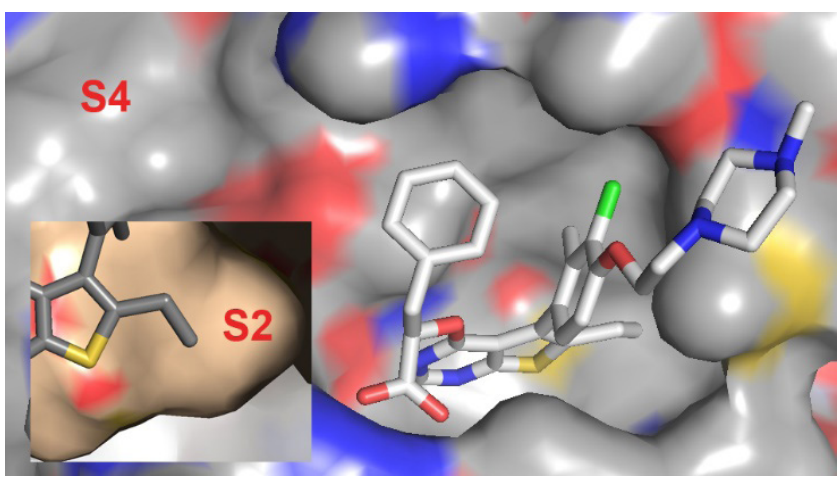

6. Ábra. A 17 vezérmolekula MCL-1 komplexének röntgenszerkezete (PDB:6QYO). A kiegészítő kép az S2 kötőzseb egy részletét mutatja.

A vezérmolekula optimálását az S2 kötőzsebbe nyúló etilcsoport változtatásával kezdtük. A szerkezeti információk alapján azt vártuk, hogy csak minimális átalakítást végezhetünk a hatóanyagunkon az MCL-1-hez való kötődés elrontása nélkül. Örömmel tapasztaltuk, hogy a telítetlen oldalláncot hordozó 2-metil-propénil- (19) és 1-propinil-származék (20) is jelentős affinitást mutatott és emellett a sejtes aktivitásuk is számottevően javult (7. Ábra). Ugyanakkor meglepő eredmény volt a nagyobb térigényü furil oldalláncot hordozó 21 vegyület $10 \mathrm{nM}$ kötődése és 320 nM sejtes aktivitása. A röntgenszerkezet alapján e csoport már nem fért volna be az S2-es kötőzsebbe, ezért a 
kötődés csökkenésére számítottunk. Az eredmények arra utaltak, hogy az MCL-1 fehérje számottevő konformációs mozgékonysággal rendelkezik és képes úgy átrendeződni, hogy helyet biztosítson az öttagú heterociklusnak. A nagyobb térigényű kétgyürüs benzofuril-csoportot is beépítettük a tienopirimidin 6-os helyzetébe (22). Bár a kötődés számottevő maradt, de a furánanalogonhoz képest elromlott, ami arra utalt, hogy elértük a fehérje kötőzsebe befogadóképességének határát.
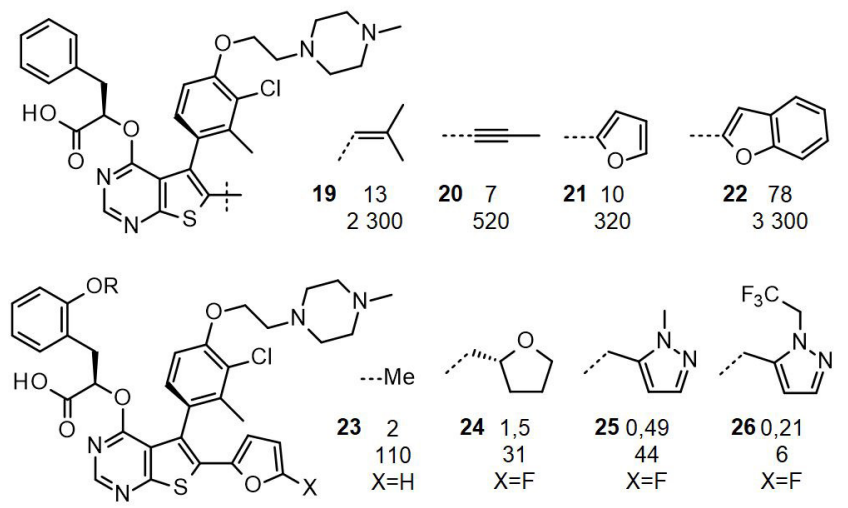

7. Ábra. Az MCL-1 gátló vezérmolekula optimálása az S2 és S4 kötőzsebben. A vegyületek MCL-1 kötődésének FP (19-23) és QA (24-26) mérésekből számított eK $\mathrm{i}_{\mathrm{i}}$ értéke nM-ban kifejezve (felső szám) és H929 sejtpusztítás MTT módszerrel mért $\mathrm{IC}_{50}$ értéke nM-ban kifejezve (alsó szám).

A 6-os helyzetủ furángyürüt rögzítve belefogtunk a tejsav fenilcsoportjának változtatásába. Egyszerü metoxicsoportot beépítve (23) a sejtes aktivitást sikerült $110 \mathrm{nM}$-ra javítanunk, míg az MCL-1 kötődés elérte a vizsgálati módszerünk alsó határának számító 1-2 nM tartományt, ezért a továbbiakban egy új, ún. „quench assay-t” (QA) vezettünk be, melynek alsó mérési határa az alacsony pikomólos tartományban volt. Hasonló további előrelépést, 1,5 nM kötődést és ezzel együtt $31 \mathrm{nM}$ aktivitást hozott a tetrahidrofuranil-metil helyettesítő és a furilcsoport 5-ös helyzetébe egy fluoratom egyidejü beépítése (24).

Hasonló in vitro tulajdonságokkal rendelkezett a pirazolilmetil-csoportot hordozó 25 vegyület is (7. Ábra). E vegyületet mutatott sajátságai miatt in vivo vizsgálatoknak is alávetettük. Mivel farmakokinetikai sajátságai alapján megfelelő expozícióra számíthattunk intravénás adagolás esetén, így az MCL-1 gátlásra érzékeny AMO1 ráksejtvonalat egérbe ültettük (xenograft) és az egereket $\mathbf{2 5}$ oldatával kezeltük. A hatóanyag adagolása után adott idővel a daganatos sejteket vizsgálva megállapítottuk, hogy dózisfüggő mértékben sikerült apoptózis indukciót kiváltanunk, amelyet a folyamatra jellemző PARP hasítás mértékével jellemeztünk (1. Táblázat). Mivel $25 \mathrm{mg} / \mathrm{kg}$ dózisban adva még 16 óra elteltével is jelentős farmakodinámiás (PD) jelet mértünk, így megvizsgáltuk azt is, hogy a 25 vegyületet 5 egymást követő napon (QD5) ebben a dózisban adagolva hogyan változik az egérbe ültetett daganat mérete (1. Táblázat). A kezelés alatt tumor regressziót észleltünk és a kezelés leállítása után majd 3 hétig tartott mire az újra növekedő daganatok mérete elérte a határként kijelölt $500 \mathrm{~mm}^{3}$-t.
A szerkezeti vizsgálatok kimutatták, hogy 25 pirazolrészletének nitrogénatomja kiválóan alkalmas a vegyület további növelésére és ennek szisztematikus változtatásával jutottunk a 26-os vegyülethez, amely S63845 jelöléssel került leírásra. 26 affinitásában érdemi előrelépést észleltünk és sejtes aktivitása is kiemelkedő volt $\left(\mathrm{IC}_{50}=6 \mathrm{nM}\right)$. A farmakodinámiás vizsgálatok azt mutatták, hogy $2612,5 \mathrm{mg} /$ kg-os dózisban is tartós apoptózis indukciót váltott ki és hatékonyan gátolta a daganat növekedését is ebben a dózisban (1. Táblázat). E vegyület biológiai aktivitása lehetővé tette, hogy az MCL-1 gátlás biztonságosságával kapcsolatos vitás kérdésekre is választ kapjunk. Az MCL-1 fehérjét nélkülözö (ún. knock-out, vagy $\mathrm{KO}$ ) genetikusan módosított egerek ugyanis káros szervi elváltozásokat mutattak és kérdéses volt, hogy ezek az MCL-1 biológiai funkciójából (programozott sejthalál szabályozása), vagy esetleg más szerepéből eredtek (pl. fehérjekomplexekben betöltött szerkezet összetartó funkció). MCL-1 függő rákot hordozó egér betegségmodellben sikerült $\mathbf{2 6}$ adagolásával az állatok jelentős részét tartósan meggyógyítani, miközben az állat egyéb szerveiben nem észleltünk káros elváltozást. ${ }^{9}$ Ezen eredményekből bizodalmat merítve léptünk be az optimálási folyamat záró stádiumába.

1. Táblázat. Farmakodinámiás aktivitás $12.5 \mathrm{mg} / \mathrm{kg}$ dózisban, i.v. bólus adagolás után 16 óra elteltével $(\mathrm{n}=3)$ és tumornövekedés-gátlás AMO1 egér xenograft modelben QD5 i.v. bólus adagolással $(\mathrm{n}=8)$.

\begin{tabular}{cccccc}
\hline & $\begin{array}{c}\text { PD } \\
\text { válasz }\end{array}$ & $\begin{array}{c}\text { dózis } \\
(\mathrm{mg} / \mathrm{kg})\end{array}$ & $\begin{array}{c}\text { \%TGI } \\
\text { (nap) }\end{array}$ & $\begin{array}{c}\text { \%TGI max } \\
\text { (nap) }\end{array}$ & Relapszus $^{\mathrm{a}}$ \\
\hline $\mathbf{2 5}$ & $55^{\mathrm{b}}$ & 25 & $120,5(7)$ & $147,5(2)$ & 23 \\
$\mathbf{2 6}$ & 309 & 12,5 & $118,9(7)$ & $152,8(2)$ & 32 \\
$\mathbf{2 8}$ & 129 & 12,5 & $120(7)$ & $134,6(4)$ & 28 \\
$\mathbf{3 0}$ & 237 & 6,25 & $106(7)$ & $132,4(2)$ & 14 \\
$\mathbf{3 1}$ & 285 & 6,25 & $189,5(4)$ & $189,5(4)$ & 38 \\
$\mathbf{3 2}$ & 60 & 6,25 & $121,2(4)$ & $130,8(2)$ & 21 \\
\hline
\end{tabular}

a A kezelés után eltelt idő, mikorra a csoport medián tumormérete eléri az $500 \mathrm{~mm}^{3}$-t.

b $25 \mathrm{mg} / \mathrm{kg}$ dózisban adagolva.

\subsection{A klinikai gyógyszerjelölt kiválasztása}

Bár 26 kiemelkedő affinitással és szelektivitással kötődött az MCL-1 fehérjéhez, és ezen keresztül sejthalált indukált mind in vitro, mind in vivo betegség modellekben, a fluorfuril-csoport jelenlétéből eredő fényérzékenysége miatt nem léphetett tovább a kutatás-fejlesztési folyamatban. A fényérzékenység kiküszöbölésére a hasonló szerkezetü 4-fluorfenil helyettesítő beépítése jelentett megoldást. A késői vezérmolekula-optimálás a $\mathbf{2 7}$ metoxi-pirimidin-származékból indult (8. Ábra). Ez a vegyület 360 pM affinitás mellett $15 \mathrm{nM}$ sejtes aktivitást mutatott. A metoxicsoport morfolinra való cseréje (28) bár kissé csökkentette az affinitást, de megőrizte a sejtes aktivitást. Amennyiben 28-at a farmakodinámiai modellben vizsgál-tuk, számottevő biológiai választ észleltünk (1. Táblázat). Örömmel láttuk, hogy 
a tumoros egereket kezelve tartós tumorregressziót értünk el és a kezelés befejezése után 24 nappal érte csak el a tumorok átlagos mérete az $500 \mathrm{~mm}^{3}$-t.

A pirimidingyürü helyettesítője az S4-es kötőzsebben foglal helyet, amely viszonylag kevés kölcsönhatási pontot kínál. A poláris alifás csoportokat a heteroaromás 2-furil-csoportra cserélve (29) mégis számottevő affinitásnövekedést (81 pM) értünk el, ami a sejtes aktivitás javulásában is megmutatkozott. Érdekes változást hozott a 4-metil-3-piridil helyettesítő beépítése. Bár a 30-as vegyület affinitása 730 pM-ra nőtt, sejtes aktivitása ugyanakkor 1,7 nM-ra csökkent. A két érték eltérő irányú változásáért feltehetően a megjavult sejtbejutási képesség felel. Az in vivo vizsgálat során 30 kiemelkedő farmakodinámiás aktivitást mutatott: a PARP fehérje hasított formájának mennyisége 16 óra elteltével 237-szeresére nőtt (1. Táblázat), amely az eddig mért legmagasabb érték. A kiváló $\mathrm{PD}$ válasz előrevetítette a vegyület tumornövekedés gátló hatását is. QD5 adagolást követően a korábbiakhoz képest csökkentett, $6,25 \mathrm{mg} / \mathrm{kg}$ dózisban adagolva is értékelhető regressziót értünk el és a daganatok ismételt növekedését is sikerült késleltetni.

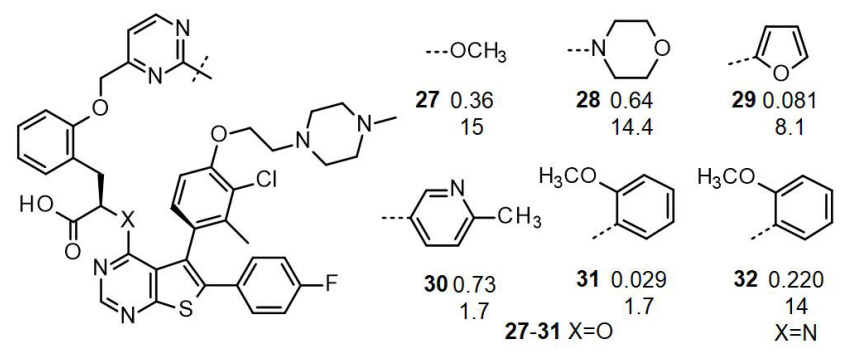

8. Ábra. Az MCL-1 gátló vezérmolekula optimálásának záró szakasza. A vegyületek MCL-1 kötődésének QA mérésekből számított eK $\mathrm{i}_{\mathrm{i}}$ értéke nM-ban kifejezve (felső szám) és H929 sejtpusztítás MTT módszerrel mért $\mathrm{IC}_{50}$ értéke nM-ban kifejezve (alsó szám).

Számos további helyettesítőt is megvizsgálva a legjobb eredményt a 31, 2-metoxifenil-csoporttal módosított vegyülettel értük el. Az S64315 néven preklinikai fejlesztésre kiválasztott vegyület 29 pM affinitást mutatott az MCL-1 fehérjéhez és $1,7 \mathrm{nM}$ sejtes aktivitása is kiváló. Jó farmakokinetikai sajátságai miatt az in vivo PARP hasítási vizsgálatokban (PD) is kiválóan szerepelt és a tumornövekedés gátlása terén is a legjobb volt: a kezelés végére szinte teljesen eltüntek a tumorok a vizsgálati egerekből és a visszanövésüket a kezelések befejezése után sikerült egy hónappal késleltetni (1. Táblázat). A vegyületet egyéb, itt nem részletezett tulajdonságai is alkalmassá tették a fejlesztésre, ${ }^{10}$ ami a jelenleg is folyó klinikai vizsgálatokban teljesedett ki. Előállítottuk a preklinikai kandidátus aminosav analogonját is. A 32 vegyület 220 pM affinitása és 14 nM sejtes aktivitása is némiképp elmaradt 31-től. Bár 32 az in vivo farmakodinámiás és tumornövekedés gátlás vizsgálatokban is értékelhető aktivitást mutatott, ez jelentősen elmaradt a hidroxisav analogontól.

\section{3. Összefoglalás}

NMR alapú szűrés segítségével több olyan fragmenst sikerült azonosítanunk, melyek kötődést mutattak az MCL-1 fehérje BH3 kötőrégiójához. Ezek a fragmensek, melyek kötődését ortogonális módszerek is igazolták, általában a fehérjecsalád több tagjához is kötődtek. A fragmens találatok szisztematikus kémiai változtatását követően a tieno[2,3-d] pirimidin alapvázat tartalmazó sorozatot választottuk ki további optimálásra. Ennek során áttörést hozott a felismerés, hogy az alapváz 5-ös helyzetébe orto-helyettesítőt hordozó aromás gyürüt építve kiváló szelektivitást érhetünk el a fehérjecsaládon belül az MCL-1 fehérje gátlásában. Ez a kémiai változtatás egy újabb kiralitáselem megjelenését eredményezte. Az atropoizomerek kromatográfiásan elválaszthatóak voltak és megfelelő stabilitást mutattak a vizsgálati körülmények között. A helyettesítők további finomhangolásával és egy bázikus nitrogén beépítésével sikerült sejtes aktivitást mutató vezérmolekuláig jutnunk.

A vezérmolekula optimálását szerkezeti biológiai információ is segítette. Ennek során megfigyeltük, hogy az MCL-1 fehérje képes volt olyan molekulákkal is erős kölcsönhatást kialakítani, amelyek a rendelkezésre álló szerkezeti adatok alapján nem fértek volna el a kötőzsebben. A további kémiai változtatások eredményeként sikerült a kötődést és a sejtes aktivitást is olyan mértékben javítanunk, hogy a vegyületeink in vivo modellekben is képesek voltak beindítani a programozott sejthalált. A kutatási program ezen stádiumában, hála a rendelkezésre álló vegyületek hatékonyságának, megnyugtató választ tudtunk adni az MCL-1 fehérje gátlásának biztonságosságával kapcsolatos felvetésekre is. A vezérmolekula további finomhangolásával S64315-höz jutottunk, amit előnyös tulajdonságai miatt kiválasztottunk preklinikai fejlesztésre. A vegyület jelenleg klinikai vizsgálati fázisban van S64315/MIK665 kódnéven.

\section{Köszönetnyilvánítás}

A fenti eredmények egy többrésztvevős nemzetközi kutatás során születtek. Ezúton köszönöm az összes szabadalmi bejelentés és közlemény társszerzőinek lelkiismeretes munkájukat az elmúlt évtizedben, valamint a Servier Kutatóintézet kollektívájának, és azon belül is kiemelten az Analitikai Kémiai Divízió munkatársainak folyamatos és magas szintű támogatását! 


\section{Hivatkozások}

1. Green, D. R.; Llambi, F. Cell Death Signaling. Cold Spring Harbour Perspect. Biol. 2015, 7, 1-24. https://doi.org/10.1101/cshperspect.a006080

2. Hanahan, D.; Weinberg, R. A. Cell 2011, 144, 646-674. https://doi.org/10.1016/j.cell.2011.02.013

3. Beroukhim, R.; Mermel, C. H.; Porter,D.; Guo Wei, Raychaudhuri, S.; Donovan, J.; Barretina, J.; Boehm, J. S.; Dobson, J.; Urashima, M.; Mc Henry,K. T.; Pinchback, R. M.; Ligon, A. H.; Cho, Y-J.; Haery, L.; Greulich, H.; Reich, M.; Winckler, W.; Lawrence, M. S.; Weir, B. A.; Tanaka, K. E.; Chiang, D. Y.; Bass, A. J.; Loo, A.; Hoffman, C.; Prensner, J.; Liefeld, T.; Gao, Q.; Yecies, D.; Signoretti, S.; Maher, E.; Kaye, F. J.; Sasaki, H.; Tepper, J. E.; Fletcher, J. A.; Tabernero, J.; Baselga, J.; Tsao, M-S.; Demichelis, F.; Rubin, M. A.; Janne, P. A.; Daly, M. J.; Nucera, C.; Levine, R. L.; Ebert, B. L.; Gabriel, S.; Rustgi, A. K.; Antonescu, C. R.; Ladanyi, M.; Letai, A.; Garraway, L. A.; Loda, M.; Beer, D. G.; True, L. D.; Okamoto, A.; Pomeroy, S. L.; Singer, S.; Golub, T. R.; Lander, E. S.; Getz, G.; Sellers, W. R.; Meyerson, M. Nature 2010, 463, 899-905. https://doi.org/10.1038/nature08822

4. a) Wei, G.; Margolin, A. A.; Haery, L.; Brown, E.; Cucolo, L.; Julian, B.; Shehata, S.; Kung, A. L.; Beroukhim, R.; Golub, T. R. Cancer Cell 2012, 21, 547-562. https://doi.org/10.1016/j.ccr.2012.02.028

b) Barlaam, B.; De Savi, C.; Drew, L.;Ferguson, A.; Ferguson, D.; Gu, C.; Hawkins, J. W.; Hird, A.; Lamb, M.; O’Connell, N.; Pike, K.; Proia, T.;San Martin, M.; Vasbinder, M.; Varnes, J.;Wang, J.; Shao, W. Cancer Research, 2018, $78,1650-1650$. https://doi.org/10.1158/1538-7445.AM2018-1650

5. Juin, P., Geneste, O., Gautier, F., Depil, S. \& Campone, M. Nat. Rev. Cancer 2013, 13, 455-465. https://doi.org/10.1038/nrc3538

6. a) Caenepeel, S.; Brown, S. P.; Belmontes, B.; Moody, G.; Keegan, K. S.; Chui, D.; Whittington, D. A.; Huang, X.; Poppe, L.; Cheng, A. C.; Cardozo, M.; Houze, J.; Li, Y.; Lucas, B.; Paras, N. A.; Wang, X.; Taygerly, J. P.;

Vimolratana, M.; Zancanella, M.; Zhu, L.; Cajulis, E.; Osgood, T.; Sun, J.; Damon, L.; Egan, R. K.; Greninger, P.; McClanaghan, J. D.; Gong, J.; Moujalled, D.; Pomilio, G.; Beltran, P.; Benes, C. H.; Roberts, A. W.; Huang, D. C.; Wei, A.; Canon, J.; Coxon, A.; Hughes, P. E. Cancer Discov. 2018, $8,1582-1597$

https://doi.org/10.1158/2159-8290.CD-18-0387

b) Tron, A.E.; Belmonte, M.A.; Adam, A.; Aquila, B.M.; Boise, L.H.; Chiarparin, E.; Cidado, J.; Embrey, K.J.; Gangl, E.; Gibbons, F.D.; Gregory, G.P.; Hargreaves, D.; Hendricks, J.A.; Johannes, J.W.; Johnstone, R.W.; Kazmirski, S.L.; Kettle, J.G.; Lamb, M.L.; Matulis, S.M.; Nooka, A.K.; Packer, M.J.; Peng, B.; Rawlins, P.B.; Robbins, D.W.; Schuller, A.G.; Su, N.; Yang, W.Z.; Ye, Q.; Zheng, X.L.; Secrist, J.P.; Clark, E.A.; Wilson, D.M.; Fawell, S.E.; Hird, A.W. Nature Comm. 2018, 9, 5341.

https://doi.org/10.1038/s41467-018-07551-w c) Shaw, S.; Bian, Z.; Zhao, B.; Tarr, J. C.; Veerasamy, N.; Ok, K.; Johannes Belmar, L.; Arnold, A. L.; Fogarty, S. A.; Perry, E.; Sensintaffar, J. L.; Camper, D. V.; Rossanese, O. W.; Lee, T.; Olejniczak, E. T.; Fesik, S. W. J. Med. Chem. 2018, 61, 2410-2421.

https://doi.org/10.1021/acs.jmedchem.7b01155

d) Bruncko, M.; Wang, L.; Sheppard, G. S.; Phillips, D. C.; Tahir, S. K.; Xue, J.; Erickson, S.; Fidanze, S.; Fry, E.; Hasvold, L.; Jenkins, G. J.; Jin, S.; Judge, R. A.; Kovar, P. J.; Madar, D.; Nimmer, P.; Park, C.; Petros, A. M.; Rosenberg, S. H.; Smith, M. L.; Song, X.; Sun, C.; Tao, Z-F.; Wang, X.; Xiao, Y.; Zhang, H.; Tse, C.; Leverson, J. D.; Elmore, S. W.; Souers, A. J. J. Med. Chem. 2015, 58, 2180-2194.

https://doi.org/10.1021/jm501258m

7. Murray, J.; Davidson, J.; Chen, I.; Dokurno, P.; Davis, B.; Harris, R.; Jordan, A.; Matassova, N.; Pedder, C.; Ray, S.; Roughley, S.; Smith, J.; Walmsley, C.; Wang, Y.; Whitehead, N.; Williamson, D.; Casara, P.; Le Diguarher, T.; Hickman, J.; Stark, J.; Kotschy, A.; Geneste, O.; Hubbard, R.E. ACS Omega 2019, 4, 8892-8906. https://doi.org/10.1021/acsomega.9b00611

8. Szlávik, Z.; Ondi, L.; Csékei, M.; Paczal, A.; Szabó, Z.B.; Radics, G.; Murray, J.; Davidson, J.; Chen, I.; Davis, B.; Hubbard, R.E.; Pedder, C.; Dokurno, P.; Surgenor, A.; Smith, J.; Robertson, A.; LeToumelin-Braizat, G.; Cauquil, N.; Zarka, M.; Demarles, D.; Perron-Sierra, F.; Geneste, O.; Kotschy, A. J. Med. Chem. 2019, 62, 6913-6924. https://doi.org/10.1021/acs.jmedchem.9b00134

9. Kotschy, A.; Szlavik, Z.; Murray, J.; Davidson, J.; Maragno, A. L.; Le Toumelin-Braizat, G.; Chanrion, M.; Kelly, G. L.; Gong, J.; Moujalled, D. M.; Bruno, A.; Csekei, M.; Paczal, A.; Szable, Z. B.; Sipos, S.; Radics, G.; Proszenyak, A.; Balint, B.; Ondi, L.; Blasko, G.; Robertson, A.; Surgenor, A.; Dokurno, P.; Chen, I.; Matassova, N.; Smith, J.; Pedder, C.; Graham, C.; Studeny, A.; Lysiak-Auvity, G.; Girard, A.; Gravé, F.; Segal, D.; Riffkin, C. D.; Pomilio, G.; Galbraith, L. C. A.; Aubrey, B. J.; Brennan, M. S.; Herold, M. J.; Chang, C.; Guasconi, G.; Cauquil, N.; Melchiore, F.; Guigal-Stephan, N.; Lockhart, B.; Colland, F.; Hickman, J. A.; Roberts, A. W.; Huang, D. C. S.; Wei, A. H.; Strasser, A.; Lessene, G.; Geneste, O. Nature 2016, 538, 477-482. https://doi.org/10.1038/nature19830

10. Szlávik, Z.; Csékei, M.; Paczal, A.; Szabó, Z.B.; Sipos, S.; Radics, G.; Proszenyak, A.; Balint, B.; Murray, J.; Davidson, J.; Chen, I.; Dokurno, P.; Surgenor, A. E.; Daniels, Z. M.; Hubbard, R.E.; Le Toumelin-Braizat, G.; Claperon, A.; Lysiak-Auvity, G.; Girard, A-M.; Bruno, A.; Chanrion, M.; Colland, F.; Maragno, A-L.; Demarles, D.; Geneste, O.; Kotschy, A. J. Med. Chem. 2020, 63, 13762-13795. https://doi.org/10.1021/acs.jmedchem.0c01234 


\section{The discovery of selective MCL-1 inhibitors}

Apoptosis, an evolutionary highly conserved form of programmed cell death, is an essential process for the elimination of no longer needed and dangerous cells. Myeloid cell leukemia 1 (MCL-1), whose upregulation in human cancers is associated with high tumor grade, poor survival, and resistance to chemotherapy, an antiapoptotic member of the BCL-2 family of proteins, has emerged as an attractive target for cancer therapy. The longstanding interest in MCL-1 as a target and the late emergence of MCL-1 targeting drug candidates suggest that drugging MCL-1 is highly desirable but also very challenging.

Our objective was to develop a potent and selective inhibitor of MCL-1, which would restore the programmed cell death in cancer cells leading to their death, while sparing non-cancer cells. To identify the chemistry starting points we ran an NMR-based fragment screen using the $\mathrm{BH} 3$ protein fragment as a control to ensure that we select only fragments that bind to the appropriate region of MCL-1. As a counter screen we also routinely assessed binding to some closely related proteins like BCL-2 or BCL- $\mathrm{x}_{\mathrm{L}}$. Systematic chemical modification of the identified hits led to the emergence of the thieno[2,3-d]pyrimidines (1) as the validated hit series.

The exploration of the different vectors around this fragment was well tolerated and we obtained several compounds showing low micromolar affinity for MCL-1, although they also had similar affinity for BCL-2. Unfortunately, at this stage of the project we had only limited structural information and some of the SAR suggested the presence of multiple binding modes, which complicated the analysis of the obtained data and its use for planning. A major breakthrough was achieved when we prepared the first 5-phenyl analog with a hindered rotation around the biaryl axis (10). The atropoisomers were separated and found stable under assay conditions. This structural feature led to an increased affinity for MCL1 and reversely a decreased affinity for the other BCL-2 family members resulting in an excellent selectivity. Finetuning the substitution pattern of the benzene ring and moving to a phenyl lactic acid substituent in position 4 led to high affinity $(51 \mathrm{nM}, \mathbf{1 3})$.

Another significant advancement was the identification of amine substituents whose addition improved the cell penetrance of our compounds and led to cell killing in an MCL-1 sensitive model. Optimization of the basic group resulted in our lead compound 17, a highly potent and selective MCL-1 inhibitor inducing apoptosis and cell killing in the micromolar range. We assessed the amino acid analog of our lead and found it slightly less potent, while the stereoisomers of $\mathbf{1 7}$ all showed a significant drop of affinity, which made them useful negative controls in biological studies.

We pursued the structure-guided optimization of our lead molecule into two separate directions: making minor changes to the ethyl group in the 6-position, and a more ambitious growing of the lactic acid towards the $\mathrm{S} 4$ pocket. In spite of the fact that the X-ray structure of the 17:MCL-1 complex (PDB:6QYO) showed only a little room around the ethyl group, we found that the introduction of monocyclic and bicyclic aromatic compounds was well tolerated, the former giving the more potent compounds, such as $\mathbf{2 1}$. This is a clear indication of the conformational flexibility of the protein in this region.

Fixing the 2-furyl substitution in the 6-position we continued with the optimization of the lactic acid part. Of the substituents tested the pyrazolylmethyl derivatives showed consistently high affinity at or below the single digit nanomolar range, and the cellular activities also dropped below $50 \mathrm{nM}$. These compounds (e.g. 25) were potent enough to induce apoptosis in a xenografted mice disease model (AMO1), evidenced both by the appearance of the apoptosis hallmarks such as Caspase-3 and PARP cleavage, and by the induction of tumor regression following i.v. bolus treatment on 5 consecutive days. The most active compound in this series 26 (a.k.a. S63845) was potent enough to address also some of the biological concerns related to the inhibition of MCL-1.

Some of the unfavorable properties of the furyl-substituted MCL-1 inhibitors prompted us to move away from this substituent to the 4-fluorophenyl group. The optimal bridging motif towards the $\mathrm{S} 4$ pocket in this subseries was the 4-pyrimidylmethyl (27-32).

The introduction of a diverse set of substituents onto the pyrimidine ring was well tolerated resulting in compounds with high affinity (below $1 \mathrm{nM}$ ) and good cellular activity $\left(\mathrm{IC}_{50} \mathrm{~s}\right.$ in the 1.7-15 $\mathrm{nM}$ range). The potency of the compounds was successfully translated into the in vivo setting leading to a strong pharmacodynamic response and subsequently to tumor regression. The relative efficiency of the different compounds was assessed by comparing their tumor growth inhibition as well as the time it took for the tumors to regrow following the last treatment. The most active compounds were characterized in more detail and $\mathbf{3 1}$ emerged as our candidate for preclinical development. This compound (a.k.a. S64315/MIK665) was later progressed into clinical development. 